\title{
Gerinckorrekciós mütétek háromdimenziós hatékonysági vizsgálata serdülőkori idiopathiás gerincferdülésben
}

\author{
József Kristóf dr. - Márkus István dr. - Bogyó Csaba dr. \\ Tunyogi Csapó Miklós dr. - Schlégl Ádám Tibor dr.
}

Pécsi Tudományegyetem, Általános Orvostudományi Kar, Ortopédiai Klinika, Pécs

\begin{abstract}
Bevezetés: Nincs egységesen elfogadott álláspont, hogy a serdülőkori idiopathiás gerincferdülés sebészi korrekcióját melyik életkorban optimális elvégezni. Világszerte 11 éves kortól akár (kezeletlen esetben) 50-60 éves korig végeznek fúziós mútétet a betegségben, 63-83\%-os átlagos koronális síkú korrekciós hatékonysággal.

Célkitüzés: Célul tűztük ki, hogy felmérjük a gerinckorrekciós műtétek hatékonyságát három dimenzióban, illetve a páciens életkorának függvényében.

Módszerek: A vizsgálatba 23, serdülőkori idiopathiás gerincferdüléssel diagnosztizált beteget ( 12 fó 17 évnél fiatalabb, 11 fő 17 évnél idősebb) vontunk be. Minden betegnél csavaros derotációt és spondylodesist végeztünk, és a beavatkozás előtt és után EOS 2D/3D felvételeket, majd sterEOS 3D rekonstrukciókat készítettünk. A következő paramétereket számítottuk: Cobb-fok, háti kyphosis, ágyéki lordosis, apicalis csigolyarotáció, maximális csigolyarotáció. A különböző életkorú csoportok közötti különbséget kétmintás t-próbával, illetve Wilcoxon-féle próbával vizsgáltuk. Eredmények: A gerinckorrekciós mútétek során a koronális síkú eltérést 78,2\%-ban (átlagosan 55,1 Cobb-fokról 12,0 Cobb-fokra), az apicalis csigolyarotációt 56,7\%-ban (átlagosan 21,0 fokról 9,1 fokra) tudtuk korrigálni. A 17 éves életkor után operált páciensek esetén átlagosan 79,2\%-os Cobb-fok-csökkenést értünk el, míg a fiatalabb betegcsoportban 77,0\%-ban korrigáltuk a koronális fögörbületet $(\mathrm{p}=0,614)$. Az idősebb betegcsoportban szignifikánsan kevésbé sikerült az apicalis csigolyarotáció korrekciója (átlagosan 38,1\%; 21,8 fokról 12,4 fokra), mint a fiatalabb pácienseknél (átlagosan 68,5\%;20,2 fokról 6,2 fokra; p = 0,016).

Következtetés: Összességében a nemzetközi publikációknak megfelelő korrekciót értünk el. A koronális síkban közel azonos korrekciós hatékonyság figyelhető meg a különböző életkorú betegcsoportok között, a csigolyarotáció azonban 17 éves életkor előtt hatékonyabban korrigálható.
\end{abstract}

Orv Hetil. 2021; 162(39): 1573-1578.

Kulcsszavak: gerincferdülés, scoliosis, műtét, EOS 2D/3D, apicalis csigolyarotáció

\section{Three-dimensional efficacy of correction surgeries in adolescent idiopathic scoliosis}

Introduction: There is no clear recommendation for the optimal age to perform corrective surgery in adolescent idiopathic scoliosis. Fusion surgery is performed from the age of 11 to 50-60 years, with an average coronal plane correction efficiency of $63-83 \%$.

Objective: We aimed to evaluate the effectiveness of correction surgeries in three dimensions in adolescent idiopathic scoliosis. In addition, our objective was to examine the influence of the patient's age on the correction.

Methods: The study included 23 patients with adolescent idiopathic scoliosis ( 12 patients younger than 17 years, 11 patients older than 17 years). All patients underwent screw-derotation and spondylodesis and underwent EOS 2D/3D imaging before and after the operation, followed by sterEOS 3D reconstructions. The following parameters were calculated: Cobb degree, thoracic kyphosis, lumbar lordosis, apical vertebral rotation, maximal vertebral rotation. Differences between different age groups were examined by paired-sample t-test and Wilcoxon rank sum test. Results: The mean efficiency of correction surgeries was $78.2 \%$ in the coronal plane (from an average of 55.1 Cobb degrees to 12.0 Cobb degrees) and $56.7 \%$ in the axial plane (from an average of 21.0 degrees to 9.1 degrees). We achieved an average $79.2 \%$ reduction of Cobb angle in patients operated after the age of 17 years, which was $77.0 \%$ 
in the younger group $(\mathrm{p}=0.614)$. Apical vertebral rotation correction was significantly less successful in the elderly group (mean $38.1 \%$; from 21.8 degrees to 12.4 degrees) than in patients operated before the age of 17 years (mean $68.5 \%$; from 20.2 degrees to 6.2 degrees; $p=0.016$ )

Conclusion: We achieved scoliosis correction in line with the international publications. Nearly the same correction efficiency was observed between different age groups of patients in the coronal plane. However, vertebral rotation can be derotated more effectively before the age of 17 years.

Keywords: scoliosis, surgery, EOS 2D/3D, apical vertebral rotation

József K, Márkus I, Bogyó Cs, Tunyogi Csapó M, Schlégl ÁT. [Three-dimensional efficacy of correction surgeries in adolescent idiopathic scoliosis]. Orv Hetil. 2021; 162(39): 1573-1578.

(Beérkezett: 2021. február 14.; elfogadva: 2021. március 18.)

\section{Rövidítések}

AVR = (axial vertebral rotation $)$ axiális csigolyarotáció; apical$\mathrm{AVR}=($ apical axial vertebral rotation $)$ apicalis csigolyarotáció; $\mathrm{CT}=$ (computed tomography) komputertomográfia; EOS 2D/3D = két- és háromdimenziós, kis dózisú röntgenképalkotás; maxAVR $=($ maximal axial vertebral rotation $)$ maximális csigolyarotáció; TKP = Tématerületi Kiválósági Program

A serdülőkori idiopathiás gerincferdülés a 10-18 éves életkorban megjelenő, a teljes populáció $1-3 \%$-át érintő gerincdeformitás [1]. A koronális és sagittalis mellett transzverzális síkú deformáció is megjelenik, ami a betegség háromdimenziós természetét adja [2]. A gerincdeformitás mértékét anteroposterior teljes gerinc-röntgenfelvételeken hagyományosan a Cobb-módszerrel határozzuk meg, amely a görbületet alkotó végcsigolyák zárólemezeire vetített merőlegesek kiegészítő szögét jelenti [3]. A betegség diagnosztikájában egyre inkább előtérbe kerül az EOS 2D/3D képalkotás, amely alacsony sugárterhelés mellett, álló testhelyzetben, 3D rekonstrukcióra alkalmas kétsíkú röntgentechnika [4]. A mútéti indikációt a biológiai érettséget is figyelembe véve alapvetően a 45-50 Cobb-fok feletti súlyos görbületek jelentik [5].

A mútét elvégzéséhez optimális életkorra nincs egyértelmü ajánlás. Bao és mtsai 13 éves életkor alatti, Risser 0 -ás csontérettségü pácienseknél is végeztek gerincfúziót [6]. A korai mútét átlagosan $2-3 \mathrm{~cm}$-rel alacsonyabb gerincmagasságot eredményezett, a biológiailag érettebb betegcsoporttal összevetve. Lonner és mtsai ezzel ellentétben olyan, serdülőkorban kialakult gerincferdüléssel diagnosztizált betegeket vizsgáltak, akiknél felnőttként, átlagosan 43 éves korban történt a fúziós mütét. Megállapításaik szerint a később végzett gerinckorrekció hoszszabb mütéti idővel, nagyobb komplikációs rátával és több szegmentumra kiterjedő fúzióval járt a serdülőkorban elvégzett beavatkozásokhoz képest [7]. Deviren és mtsai a páciens életkorának növekedésével a görbületi rugalmasság csökkenését mutatták ki [8].
A mútéti eredményesség meghatározásában központi szerepet játszik a koronális síkú korrekciós hatékonyság felmérése, amelynek során a mütéttel elért Cobb-fokcsökkenést adjuk meg a műtét előtti Cobb-fok százalékában [9]. Az arany standardként használt transpedicularis csavaros implantátumok használatával Jaquith és mtsai 73\%-os koronális síkú korrekciós hatékonyságot értek el [10]. A korrekció mértékét számos faktor befolyásolhatja (például a gerincmobilitás, osteotomiák, csavarok száma), amelyek figyelembevételével 63-83\%-os átlagos koronális korrekciós hatékonyság található a szakirodalomban $[11,12]$.

A gerincdeformitások sagittalis síkú elemzése és esetleges korrekciója szintén fontos tényező, hiszen az esetleges nyílirányú kiegyensúlyozatlanság jelentős negatív hatással van a páciensek életminőségére [13]. A serdülökori scoliosisos esetek többségére jellemző háti hypokyphosist a korrekciós mútétek pozitív irányban képesek befolyásolni $[11,14]$.

Az axiális síkban történő korrekció kiemelt fontosságú, hiszen a mútétet követő esetleges nagymértékű residualis bordadeformitás jelentős hatással van a posztoperatív életminőségre [15]. Ilharreborde és mtsai mütétet követően az apicalis csigolyarotáció (apicalAVR) átlagosan 48,3\%-os csökkenését mérték EOS 2D/3D módszerrel [16]. Az ezt megelőző megbízhatósági vizsgálatok során a mütét előtt és után mért EOS 3D paraméterek reprodukálhatósága egyaránt jónak bizonyult [17].

\section{Célkitüzés}

Vizsgálatunk célja a kutatócsoportunk által végzett gerinckorrekciós mütétek hatékonyságának meghatározása volt EOS 2D/3D képalkotás segítségével serdülőkori idiopathiás gerincferdülésben. Emellett célul tűztük ki a pácienséletkor befolyásoló szerepének vizsgálatát a korrekciós hatékonyságra. 


\section{Módszerek}

\section{Betegpopuláció}

Az intézményi etikai engedélyezést követően prospektív betegregisztert hoztunk létre. A regiszterbe beválasztottunk minden olyan pácienst, akinél mútéti indikációt elérő serdülőkori idiopathiás gerincferdülés igazolódott. Kizártuk a vizsgálatból azokat a betegeket, akiknél ismert eredetú volt a gerincferdülés, 10 éves kor előtt alakult ki gerincgörbületük, nem volt mútéti indikáció vagy történt megelőző gerincmütét, illetve volt társuló mozgásszervi megbetegedésük. Emellett kizártuk a vizsgálatból azon pácienseket, akiknél nem történt mútét előtti vagy közvetlen mütét utáni EOS $2 \mathrm{D} / 3 \mathrm{D}$ képalkotás.

A beválasztott 23 beteg gerinckorrekciós mútétjét 2019-2020 folyamán végeztük el. Átlagéletkoruk 17,2 év volt a mútét napján. 12 páciens volt 17 év alatti, 11 fó 17 évnél idősebb. Görbületi súlyosságuk átlagosan 55,1 Cobb-fok volt. A páciensek Lenke-klasszifikáció szerinti beosztását az 1. táblázatban tüntettük fel [18]. A betegpopuláció 20 leányt és 3 fiút számlált, ami megfelel az operatív esetek nemzetközi irodalomban megfigyelt nemi eloszlásának [19].

\section{Korrekciós mütét}

A mütét során az arany standardnak számító transpedicularis csavarozással végzett derotációs korrekció és azt követő spondylodesis történt [20]. A korrekciós manőverek betegspecifikusan magukban foglalták a rúdderotáció, transzláció-disztrakció, kompresszió, in situ rúdhajlítás, direkt csigolyaderotáció alapelveit, szükség esetén osteotomiákkal kiegészítve [21]. Minden alkalommal a konkáv oldalon króm-kobalt ötvözetű, míg a konvex oldalon titán rúdimplantátumot használtunk. A mütéti idő átlagosan $436 \pm 124$ perc volt, a vérvesztés $1437 \pm 597 \mathrm{ml}$.

\section{EOS 2D/3D képalkotás}

A prospektív regiszterünkbe került betegekről mütét előtt maximum 1 hónappal és a mútét utáni 5 . napon EOS 2D/3D képalkotás történt. Az álló testhelyzetú, alacsony sugárterheléssel járó vizsgálat speciális „knuckles on clavicles" pozícióban történt, hogy lehetőség legyen a pontos $3 \mathrm{D}$ rekonstrukciókra. A pozíció lényege, hogy a váll 45 fokos flexiójával az ujjbegyek a kulcscsontot érintik, ezáltal a felső végtagok oldalképen sem takarják a gerincoszlopot [22].

A kétsíkú röntgenképek alapján a háti és a lumbalis gerinc, illetve a medence $3 \mathrm{D}$ rekonstrukciója készült a streEOS szoftver (V1.4.4.5297, EOS Imaging Ltd., Párizs, Franciaország) segítségével. A 3D rekonstrukció során anatómiai referenciapontok alapján (például sacrumplató) egy kezdeti modell keletkezik, amelyet egy operátor tökéletesít az adott páciens tényleges csontmorfológiájának megfelelően. Az így létrejött 3D mo-
1. táblázat |A kiválasztott betegek Lenke-klasszifikáció szerinti beosztása

$$
\text { Lenke-fócsoport }
$$
A páciensek száma (fö)

1. Szimpla háti görbület

6

2. Kettős háti görbület 6

3. Háti főgörbület ágyéki kiegészítő görbülettel 1

4. Hármas görbület

5. Szimpla ágyéki görbület

8

6. Ágyéki fögörbület háti kiegészítő görbülettel 1 Összesen 23

dell alapján számított mérőszámok megbízhatósága CTvizsgálatokkal összevetve is bizonyított [23].

A 3D modell alapján a sterEOS szoftver automatikusan kiszámítja többek között a következő gerincparamétereket: Cobb-fok, Th. I.-Th. XII. kyphosis, Th. IV.Th. XII. kyphosis, L. I.-L. V. lordosis, L. I.-S. I. lordosis, axiális csigolyarotáció (AVR) a Th. I.-L. V. csigolyákra. Az axiális csigolyarotációk adatsorából meghatároztuk az apicalAVR és a maximális csigolyarotáció (maxAVR) értékeit [24].

\section{Statisztikai analizis}

A statisztikai analízist SPSS v.23 (IBM Corp., Armonk, NY, Amerikai Egyesült Államok) szoftverrel végeztük.

Az adatsorok normáleloszlásának vizsgálatához Shapiro-Wilk-tesztet alkalmaztunk, amely alapján kétmintás t-próbával, illetve Wilcoxon-féle próbával vizsgáltuk az adatsorok közti különbségeket. Az eredményeket p<0,05 értékeknél tekintettük szignifikánsnak.

\section{Eredmények}

A mütét előtti koronális, axiális, illetve sagittalis gerincparaméterekhez képest a közvetlen posztoperatív eredményeket a 2. táblázatban tüntettük fel. A fögörbületben koronális síkban Cobb szerint 78,2\%-os mútéti korrekciót értünk el (átlagosan 55,1 Cobb-fokról 12,0 Cobb-fokra), míg az axiális síkban mérési módszertől függően 56,7\%-ban (apicalAVR átlagosan 21,0 fokról 9,1 fokra), illetve 55,2\%-ban (maxAVR átlagosan 24,1 fokról 10,8 fokra) korrigáltuk a gerincgörbületeket. Az axiális síkú paraméterek mütét előtti és utáni egymáshoz viszonyított értékeit a 3. táblázatban részleteztük.

Tapasztalataink szerint a serdülőkor végén, a 17 éves életkort elérve betegeink többségének gerincdeformitása rugalmatlanná válik. Ezt a megfigyelést alátámasztva, a mútét pillanatában 17 éves életkornál találtunk minőségi különbséget a mütéti eredményeinkben. A 17 éves kor után operált páciensek esetén a 17 évesnél fiatalabbakkal közel azonos koronális görbületi korrekciót értünk el (átlagosan 79,2\% vs. 77,0\%; p = 0,614), azonban szignifikánsan kevésbé sikerült a gerincgörbületek derotációja (apicalAVR-korrekció átlagosan 38,1\% vs. 68,5\%; p = 
A koronális, sagittalis és axiális gerincparaméterek pre- és posztoperatív értékei (átlag \pm szórás), a közöttük lévő különbség p-értékeivel. A szignifikáns p-értékek * -gal vannak jelölve

\begin{tabular}{llrl}
\hline Paraméter & Mútét elött & Mútét után & $\mathrm{p}$-érték \\
\hline Főgörbületi Cobb-fok & $55,1 \pm 0,8^{\circ}$ & $12,0 \pm 5,9^{\circ}$ & $\mathrm{p}<0,001^{*}$ \\
Fögörbületi apicalAVR & $21,0 \pm 7,3^{\circ}$ & $9,1 \pm 5,7^{\circ}$ & $\mathrm{p}<0,001^{*}$ \\
Fögörbületi maxAVR & $24,1 \pm 8,0^{\circ}$ & $10,8 \pm 6,2^{\circ}$ & $\mathrm{p}<0,001^{*}$ \\
$\begin{array}{l}\text { Kiegészítő görbületi } \\
\text { Cobb-fok }\end{array}$ & $42,7 \pm 7,7^{\circ}$ & $13,8 \pm 6,1^{\circ}$ & $\mathrm{p}<0,001^{*}$ \\
$\begin{array}{l}\text { Kiegészítő görbületi } \\
\text { apicalAVR }\end{array}$ & $10,3 \pm 5,0^{\circ}$ & $7,8 \pm 0,2^{\circ}$ & $\mathrm{p}=0,133$ \\
$\begin{array}{l}\text { Kiegészító görbületi } \\
\text { maxAVR }\end{array}$ & $12,4 \pm 4,5^{\circ}$ & $10,0 \pm 4,0^{\circ}$ & $\mathrm{p}=0,072$ \\
$\begin{array}{l}\text { Th. I.-Th. XII. } \\
\text { kyphosis }\end{array}$ & $29,6 \pm 13,4^{\circ}$ & $32,9 \pm 9,7^{\circ}$ & $\mathrm{p}=0,117$ \\
$\begin{array}{l}\text { Th. IV.-Th. XII. } \\
\text { kyphosis }\end{array}$ & $24,9 \pm 12,6^{\circ}$ & $24,9 \pm 7,9^{\circ}$ & $\mathrm{p}=0,971$ \\
$\begin{array}{l}\text { L. I.-L. V. lordosis } \\
\text { L. I.-S. I. lordosis }\end{array}$ & $56,0 \pm 11,5^{\circ}$ & $41,7 \pm 8,9^{\circ}$ & $\mathrm{p}=0,048^{*}$ \\
\hline
\end{tabular}

apicalAVR = apicalis csigolyarotáció; maxAVR = maximális csigolyarotáció

3. táblázat $\mid$ Az axiális gerincparaméterek egymáshoz viszonyított értékei (átlag \pm szórás), a közöttük lévő különbség p-értékeivel. A szignifikáns p-értékek *-gal vannak jelölve

\begin{tabular}{lrll}
\hline & apicalAVR & maxAVR & p-érték \\
\hline Főgörbületben mütét előtt & $21,0 \pm 7,3^{\circ}$ & $24,1 \pm 8,0^{\circ}$ & $\mathrm{p}<0,001^{*}$ \\
Fôgörbületben mütét után & $9,1 \pm 5,7^{\circ}$ & $10,8 \pm 6,2^{\circ}$ & $\mathrm{p}<0,001^{*}$ \\
$\begin{array}{l}\text { Kiegészítő görbületben } \\
\text { mútét előtt }\end{array}$ & $10,3 \pm 5,0^{\circ}$ & $12,4 \pm 4,5^{\circ}$ & $\mathrm{p}=0,003^{*}$ \\
$\begin{array}{l}\text { Kiegészítő görbületben } \\
\text { mútét után }\end{array}$ & $7,8 \pm 4,2^{\circ}$ & $10,0 \pm 4,0^{\circ}$ & $\mathrm{p}=0,004^{*}$ \\
& & & \\
\hline
\end{tabular}

apicalAVR = apicalis csigolyarotáció; maxAVR = maximális csigolyarotáció

0,016, illetve maxAVR-korrekció átlagosan 42,4\% vs. $64,4 \% ; p=0,020)$. A két korcsoport közti különbségeket a 4. táblázatban tüntettük fel.

\section{Megbeszélés}

Vizsgálatunk során idiopathiás serdülőkori gerincferdülés mütétje előtti és utáni EOS 2D/3D röntgenképeket elemeztünk. A gerinc és a medence $3 \mathrm{D}$ rekonstrukcióinak elemzésével átlagosan 78,2\%-os koronális síkú mútéti hatékonyságot mértünk, ami megfelel a szakirodalomban található értékeknek [25]. Klinikailag szignifikáns, több mint 10\%-os korrekciós hatékonysági különbséget találtunk a korábbi mútéti technikához képest [26]. Az irodalmi adatoknál enyhébb hypokyphosist tapasztaltunk (normokyphosis) pácienseink preoperatív értékeiben, amelyre a mútéti korrekció nem volt jelentős hatással $[11,14]$. Az L. I. és L. V. csigolyák között mért ágyéki lordosis tekintetében statisztikailag szignifikáns különbséget találtunk a mütét előtti és utáni értékeket
4. táblázat | A koronális és axiális műtéti korrekció mértéke, illetve a koronális és axiális gerincparaméterek értéke a fógörbületben a 17 éves életkor előtt és után megoperált betegcsoportokban (átlag \pm szórás), a közöttük lévő különbség p-értekeivel. A szignifikáns p-értékek * -gal vannak jelölve

\begin{tabular}{llll}
\hline Paraméter & $\begin{array}{l}17 \text { éves kor } \\
\text { alatt }\end{array}$ & $\begin{array}{l}17 \text { éves kor } \\
\text { felett }\end{array}$ & p-érték \\
\hline $\begin{array}{l}\text { Főgörbületben } \\
\text { preoperatív Cobb-fok }\end{array}$ & $56,7 \pm 10,5^{\circ}$ & $53,3 \pm 9,1^{\circ}$ & $\mathrm{p}=0,413$ \\
$\begin{array}{l}\text { Főgörbületben } \\
\text { posztoperatív Cobb-fok }\end{array}$ & $12,6 \pm 6,1^{\circ}$ & $11,3 \pm 5,8^{\circ}$ & $\mathrm{p}=0,605$ \\
$\begin{array}{l}\text { Fögörbületi Cobb-fok- } \\
\text { korrekció }\end{array}$ & $77,0 \pm 11,8 \%$ & $79,2 \pm 9,1 \%$ & $\mathrm{p}=0,614$ \\
$\begin{array}{l}\text { Fögörbületben } \\
\text { preoperatív apicalAVR }\end{array}$ & $20,2 \pm 7,1^{\circ}$ & $21,8 \pm 7,8^{\circ}$ & $\mathrm{p}=0,610$ \\
$\begin{array}{l}\text { Főgörbületben } \\
\text { posztoperatív apicalAVR }\end{array}$ & $6,2 \pm 3,7^{\circ}$ & $12,4 \pm 5,7^{\circ}$ & $\mathrm{p}=0,005^{*}$ \\
$\begin{array}{l}\text { Főgörbületi apicalAVR- } \\
\text { korrekció }\end{array}$ & $68,5 \pm 18,3 \%$ & $38,1 \pm 35,1 \%$ & $\mathrm{p}=0,016^{*}$ \\
$\begin{array}{l}\text { Fögörbületben } \\
\text { preoperatív maxAVR }\end{array}$ & $23,2 \pm 8,3^{\circ}$ & $25,1 \pm 7,9^{\circ}$ & $\mathrm{p}=0,576$ \\
$\begin{array}{l}\text { Fögörbületben } \\
\text { posztoperatív maxAVR }\end{array}$ & $7,7 \pm 3,9^{\circ}$ & $14,1 \pm 6,7^{\circ}$ & $\mathrm{p}=0,009^{*}$ \\
$\begin{array}{l}\text { Főgörbületi maxAVR- } \\
\text { korrekcó }\end{array}$ & $64,4 \pm 16,9 \%$ & $42,4 \pm 0,8 \%$ & $\mathrm{p}=0,020^{*}$ \\
& & &
\end{tabular}

korrekció

apicalAVR = apicalis csigolyarotáció $;$ maxAVR = maximális csigolyarotáció

összevetve. Ez a néhány fokos különbség véleményünk szerint klinikailag nem releváns.

Két különböző módszerrel vizsgáltunk axiális csigolyarotációs szempontú mútéti hatékonyságot. Az elterjedtebb apicalAVR-alapú vizsgálattal 56,7\%-os derotációs hatékonyságot értünk el, amely érdemben megegyezik a szakirodalmi adatokkal [27]. A scoliosis axiális dimenzióját teljeskörúbben leíró maxAVR szerinti módszerrel 55,2\%-os derotációs sikerességet mértünk [24]. A két módszer százalékos végeredményében azért nem érzékelhető érdemi különbség, mert a maxAVR az apicalAVR-nél szignifikánsan magasabb volt a preoperatív és a posztoperatív esetekben is, kiegyenlítve a kettőből számított mütéti hatékonyság mértékét. Ebből következően mindkét módszer alkalmas az axiális síkú mútéti hatékonyság értékelésére, megjegyezve azonban, hogy a maxAVR pre- és posztoperatív vizsgálatokban is kimutathatóan magasabb értékú.

Nem találtunk érdemi különbséget a 17 éves életkor előtt, illetve után operált pácienseink között a koronális korrekciós hatékonyság szempontjából, a fiatalabb korcsoportban azonban szignifikánsan magasabb derotációs hatékonyságot értünk el. A vizsgálatunkhoz hasonló életkori csoportok között Zhu és mtsai szignifikáns, átlagosan 8 Cobb-fokos különbséget találtak a korrekciós hatékonyságban, amelyet eredményeink nem támasztanak alá [28]. Az axiális síkú korrekció fontosságát jelzi, hogy a mütétet követő nagymértékû residualis bordadeformitás jelentős hatással van a posztoperatív életminőségre [15]. Rotációs szempontból Huitema és mtsai 
vizsgáltak 21 év alatt és felett elülső fúziós mútéten átesett pácienseket. A fiatalabb korcsoportban átlagosan 3 fokkal hatékonyabb derotációt értek el (26-ról 11 fokra vs. 33-ról 21 fokra) [9]. Eredményeikhez képest vizsgálatunkban magasabb derotációs hatékonysági különbséget tapasztaltunk a fiatalabb korcsoport javára. Megjegyeznénk azonban, hogy a hivatkozott holland vizsgálatban különbség volt az életkori csoportosításban, illetve a mútéttechnikában is, ezért a két vizsgálat összevetése limitált.

A vizsgálatba bevont 23 fö elegendőnek bizonyult a klinikailag szignifikáns különbségek kimutatására, eredményeinket azonban limitálja a viszonylag alacsony esetszám. Utólagos statisztikaierő-vizsgálattal a korcsoportbontások esetén tapasztaltunk 80-90\%-os értékeket, a többi eredményünk statisztikai ereje $99 \%$ feletti volt. További korlátozó tényező a beválasztott páciensek eltérô Lenke-klasszifikációja (1. táblázat), amely miatt nem standardizálható a betegpopuláció. A különböző típusú gerincdeformitások azonban lehetőséget adnak a serdülőkori gerincferdüléses esetek teljes spektrumának értékelésére, aminek következtében eredményeink általánosan hasznosíthatók.

\section{Következtetés}

A kutatócsoportunk által végzett mütéti korrekciók hatékonysága a deformitás mindhárom dimenziójában vizsgálva megfelel a nemzetközi irányadó értékeknek. Sikerült bizonyítanunk a korábbi életkorban végzett gerinckorrekciós mütétek nagyobb hatékonyságát, elsősorban az axiális gerincparaméterek tekintetében. Eredményeink alapján kijelenthető, hogy rotációs szempontból ajánlott 17 éves életkor előtt elvégezni a gerinckorrekciós mütétet serdülőkori idiopathiás gerincferdülésben.

\section{Anyagi támogatás: A tanulmány a 2020-4.1.1-TKP2020.} számú pályázat támogatásával készült.

Szerzôi munkamegosztás: J. K.: Etikai engedélyeztetés, adatgyüjtés, statisztikai elemzés, a kézirat elkészítése. M. I.: EOS 2D/3D teljes gerincképalkotás pre- és posztoperatív elvégzése, mútétek végzése. B. Cs.: A vizsgálati adminisztráció felügyelete, a betegek tájékoztatása, a beleegyező nyilatkozatok kitöltése, mütétek végzése. T. Cs. M.: A mütéti javallatok felügyelete, a mütéti protokollok standardizálása, műtétek végzése, S. Á. T.: Vizsgálatvezető, koordináló. A cikk végleges változatát valamennyi szerző elolvasta és jóváhagyta.

Érdekeltségek: A szerzőknek nincsenek érdekeltségeik.

\section{Köszönetnyilvánítás}

Köszönettel tartozunk Wesz Adriennek és a Pécsi Tudományegyetem Orvosi Képalkotó Klinikájának a vizsgálatban nyújtott segítségért.

\section{Irodalom}

[1] Weinstein SL, Dolan LA, Cheng JC, et al. Adolescent idiopathic scoliosis. Lancet 2008; 371: 1527-1537.

[2] Kadoury S, Labelle H. Classification of three-dimensional thoracic deformities in adolescent idiopathic scoliosis from a multivariate analysis. Eur Spine J. 2012; 21: 40-49.

[3] Pruijs JE, Hageman MA, Keessen W, et al. Variation in Cobb angle measurements in scoliosis. Skeletal Radiol. 1994; 23: 517520.

[4] Pasha S, Cahill PJ, Dormans JP, et al. Characterizing the differences between the 2D and 3D measurements of spine in adolescent idiopathic scoliosis. Eur Spine J. 2016; 25: 3137-3145.

[5] Lonstein, JE. Scoliosis: surgical versus nonsurgical treatment. Clin Orthop Relat Res. 2006; 443: 248-259.

[6] Bao H, Liu Z, Bao M, et al. Predicted final spinal height in patients with adolescent idiopathic scoliosis can be achieved by surgery regardless of maturity status. Bone Joint J. 2018; 100-B: 1372-1376.

[7] Lonner BS, Ren Y, Bess S, et al. Surgery for the adolescent idiopathic scoliosis patients after skeletal maturity: early versus late surgery. Spine Deform. 2019; 7: 84-92.

[8] Deviren V, Berven S, Kleinstueck F, et al. Predictors of flexibility and pain patterns in thoracolumbar and lumbar idiopathic scoliosis. Spine 2002; 27: 2346-2349.

[9] Huitema GC, Jansen RC, Ooji A, et al. Predictability of spontaneous thoracic curve correction after anterior thoracolumbar correction and fusion in adolescent idiopathic scoliosis. A retrospective study on a consecutive series of 29 patients with a minimum follow-up of 2 years. Spine J. 2015; 15: 966-970.

[10] Jaquith BP, Chase A, Flinn P, et al. Screws versus hooks: implant cost and deformity correction in adolescent idiopathic scoliosis. J Child Orthop. 2012; 6: 137-143.

[11] Sudo H, Abe Y, Kokabu T, et al. Impact of multilevel facetectomy and rod curvature on anatomical spinal reconstruction in thoracic adolescent idiopathic scoliosis. Spine 2018; 43: E1135E1142.

[12] Li Y, Yang C, Zhu X, et al. Analysis of correlation between regional implant density and the correction rate in treatment of Lenke $1 \mathrm{~A}$ and $\mathrm{BB}$ adolescent idiopathic scoliosis with pedicle screws. Medicine 2018; 97: e9488.

[13] Ilharreborde B. Sagittal balance and idiopathic scoliosis: does final sagittal alignment influence outcomes, degeneration rate or failure rate? Eur Spine J. 2018; 27(Suppl 1): 48-58.

[14] Newton PO, Fujimori T, Doan J, et al. Defining the "three-dimensional sagittal plane" in thoracic adolescent idiopathic scoliosis. J Bone Joint Surg Am. 2015; 97: 1694-1701.

[15] Mariconda M, Andolfi C, Cerbasi S, et al. Effect of surgical correction of adolescent idiopathic scoliosis on the quality of life: a prospective study with a minimum 5 -year follow-up. Eur Spine J. 2016; 25: 3331-3340.

[16] Ilharreborde B, Sebag G, Skalli W, et al. Adolescent idiopathic scoliosis treated with posteromedial translation: radiologic evaluation with a 3D low-dose system. Eur Spine J. 2013; 22: 23822391.

[17] Ilharreborde B, Steffen JS, Nectoux E, et al. Angle measurement reproducibility using EOS three-dimensional reconstructions in adolescent idiopathic scoliosis treated by posterior instrumentation. Spine 2011; 36: E1306-E1313.

[18] Lenke LG, Betz RR, Harms J, et al. Adolescent idiopathic scoliosis: a new classification to determine extent of spinal arthrodesis. J Bone Joint Surg Am. 2001; 83: 1169-1181.

[19] Morais T, Bernier M, Turcotte F. Age- and sex-specific prevalence of scoliosis and the value of school screening programs. Am J Public Health 1985; 75: 1377-1380.

[20] Liljenqvist UR, Halm HF, Link TM. Pedicle screw instrumentation of the thoracic spine in idiopathic scoliosis. Spine 1997; 22: 2239-2245. 
[21] Lee SM, Suk SI, Chung ER. Direct vertebral rotation: a new technique of three-dimensional deformity correction with segmental pedicle screw fixation in adolescent idiopathic scoliosis. Spine 2004; 29: 343-349.

[22] Pasha S, Capraro A, Cahill PJ, et al. Bi-planar spinal stereoradiography of adolescent idiopathic scoliosis: considerations in 3D alignment and functional balance. Eur Spine J. 2016; 25: 3234 3241 .

[23] Glaser DA, Doan J, Newton PO. Comparison of 3-dimensional spinal reconstruction accuracy: biplanar radiographs with EOS versus computed tomography. Spine 2012; 37: 1391-1397.

[24] József K, Schlégl ÁT, Burkus M, et al. Maximal axial vertebral rotation in adolescent idiopathic scoliosis: is the apical vertebra the most rotated? Global Spine J. 2020 Sep 16. Doi: $10.1177 / 2192568220948830$. [Epub ahead of print]

[25] Lowenstein JE, Matsumoto H, Vitale MG, et al. Coronal and sagittal plane correction in adolescent idiopathic scoliosis: a com-

\section{PÁLYÁZATI FELHÍVÁS}

\section{Gyöngyös Városi Önkormányzat pályázatot hirdet Fogorvosi feladatok ellátására}

Gyöngyös városában, vállalkozási formában, határozatlan idöre szóló feladatellátási szerződés keretében a gyöngyösi II. számú fogorvosi körzetben, a Nemzeti Egészségbiztositási Alapkezelő által kötött szerződés szerinti finanszírozással.

Pályázati feltételek, pályázat benyújtásához mellékelendő iratok:

- fogorvosi képesités,

- részletes szakmai önéletrajz,

- végzettséget igazoló okmányok másolata,

- OONYI másolata,

- 3 hónapnál nem régebbi erkölcsi bizonyítvány,

- MOK tagság igazolása,

- hozzájárulás a pályázati anyag elbírálásában résztvevők betekintés jogához.

Elönyben részesül a fogszabályozó szakvizsgával rendelkező pályázó, vagy utolsó éves jelölt a fogszabályozó szakképzésben.

A pályázat benyújtásának határideje: az Orvosi Hetilapban történő felhívás megjelenésétől számított 30 nap.

\section{A pályázat elbírálásának határideje:}

a benyúitási határidőt követő soros Képviselő-testületi ülés.

\section{A pályázat benyújtásának módja:}

- postai úton, a pályázatnak a Gyöngyös Városi Önkormányzat, Hiesz György polgármester részére (3200 Gyöngyös, Fő tér 13.) történő megküldésével,

- a kizárólag elektronikus úton történő jelentkezés érvénytelennek minősül.

\section{A feladat ellátásának időpontja:}

a feladat a döntés meghozatalától számított 2 hónap elteltével látható el.

\section{További felvilágosítás kérhető:}

Gyöngyösi Közös Önkormányzati Hivatal Közigazgatási és Intézményirányítási lgazgatóság:

dr. Horváth Gábor igazgatótól a 06-37/510-329 telefonon, illetve Nagyné Szakál Mária egészségügyi referenstöl a 37/510-353 telefonon vagy személyesen előzetes időpont- egyeztetést követően. parison between all pedicle screw versus hybrid thoracic hook lumbar screw constructs. Spine 2007; 32: 448-452.

[26] Illés ST. Reckoning: assessment of a 21 -year activity is spine surgery. [Számvetés: 21 éves gerincsebészeti tevékenység mérlege.] Orv Hetil. 2015; 156: 598-607. [Hungarian]

[27] Kato S, Debaud C, Zeller RD. Three-dimensional EOS analysis of apical vertebral rotation in adolescent idiopathic scoliosis. J Pediatr Orthop. 2017; 37: e543-e547.

[28] Zhu F, Bao H, Yan P, et al. Comparison of surgical outcome of adolescent idiopathic scoliosis and young adult idiopathic scoliosis: a match-pair analysis of 160 patients. Spine 2017; 42: E1133-E1139.

(József Kristóf dr., Nagyatád, Kolozsvári u. 49., 7500 e-mail: kristof.jozsef@bhc.hu)

\section{PÁLYÁZATI FELHÍVÁS}

\section{Gyöngyös Városi Önkormányzat pályázatot hirdet Fogszabályozási feladatok ellátására}

Gyöngyös városában, vállalkozási formában, határozatlan idöre szóló feladatellátási szerződés keretében heti 16 órában, a Nemzeti Egészségbiztosítási Alapkezelő által kötött szerződés szerinti finanszírozással.

\section{Pályázati feltételek:}

- fogorvosi képesités fogszabályozó fogorvos szakvizsgával, vagy utolsó éves jelölt a szakképzésben,

- részletes szakmai önéletrajz,

- végzettséget igazoló okmányok másolata,

- OONYI másolata,

- 3 hónapnál nem régebbi erkölcsi bizonyítvány,

- hozzájárulás a pályázati anyag elbírálásában résztvevők betekintési jogához.

A pályázat benyújtásának határideje: az Orvosi Hetilapban történő felhívás megjelenésétől számított 30 nap.

A pályázat elbírálásának határideje: a benyújtási határidőt követő soros Képviselö-testületi ülés.

A pályázat benyújtásának módja:

- postai úton, a pályázatnak a Gyöngyös Város Önkormányzata, Hiesz György polgármester részére (3200 Gyöngyös, Fő tér 13.) történő megküldésével,

- a kizárólag elektronikus úton történő jelentkezés érvénytelennek minősül.

\section{A feladat ellátásának időpontja:}

a feladat a szerződéskötést követően azonnal ellátható.

\section{További felvilágosítás kérhető:}

Gyöngyösi Közös Önkormányzati Hivatal Közigazgatási és Intézményirányítási Igazgatóság:

dr. Horváth Gábor igazgatótól a 06-37/510-329 telefonon, Nagyné Szakál Mária egészségügyi referenstöl a 37/510-353 telefonon vagy személyesen előzetes időpont- egyeztetést követően. 